\title{
Semaphorin 4D produced by human head and neck squamous cell carcinoma induces myeloid derived suppressor cells expansion from peripheral blood monocytes
}

\author{
Rania H Younis ${ }^{1}$, Kyu Lee Han ${ }^{1 *}$, Tonya Webb² \\ From 30th Annual Meeting and Associated Programs of the Society for Immunotherapy of Cancer (SITC 2015) \\ National Harbor, MD, USA. 4-8 November 2015
}

\section{Background}

Immune suppression is one of the hallmarks by which head and neck squamous cell carcinoma (HNSCC) develops a tumor permissible environment[1]. Semaphorin 4D (Sema4D), known for its various developmental, physiological and pathological effects, was recently shown to play a role in regulating the immune system[2]. Sema4D is expressed in many epithelial tumors including HNSCC[3]; yet, the effect of Sema4D on modulating the inflammatory profile within the tumor microenvironment of HNSCC remains to be elucidated.

\section{Methods}

Human HNSCC cell lines HN6 and HN13 were used to study the effect of Sema4D produced in tumor conditioned media (TCM), on myeloid and T cells separated from human peripheral blood mononuclear cells (PBMC) of healthy donors. Neutralizing anti-Sema4D antibody and Sema4D immune depletion from the TCM were carried out. Lentivirus shRNA was also used to knock down Sema4D in HNSCC-HN6 cells.

\section{Results}

Treatment of PBMC with TCM from HNSCC HN6 and HN13 cell lines resulted in a significant induction in myeloid derived suppressor cells (MDSC; $\mathrm{CD}_{3}{ }^{+} \mathrm{CD} 1 \mathrm{~b}^{+}$ HLA-DR ${ }^{-/ \text {low }}$ ) from freshly isolated $\mathrm{CD}^{+} 3^{+}$cells. This increase in MDSC corresponded with the suppression of autologous $\mathrm{T}$ cell proliferation and a reduction in IFN- $\gamma$

${ }^{1}$ School of Dentistry, University of Maryland Baltimore, Baltimore, MD, USA Full list of author information is available at the end of the article production. Blockade of Sema4D in the TCM of HN6 and HN13 using anti-Sema4D antibody resulted in a significant reduction in the MDSC population. Furthermore, TCM from HN6 Sema4D-shRNA rescued the MDSCmediated $\mathrm{T}$ cell suppression and recovered IFN- $\gamma$, compared to the control. Analysis of the recovered $\mathrm{T}$ cell population showed an increase in the effector $\mathrm{T}$ cell population $\left(\mathrm{CD} 4^{+} \mathrm{Tbet}^{+}\right.$and $\left.\mathrm{CD} 8^{+} \mathrm{Tbet}^{+}\right)$, and a decrease in regulatory $\mathrm{T}$ cells $\left(\mathrm{CD} 4^{+} \mathrm{CD} 25^{+} \mathrm{FoxP}^{+}\right)$. Mechanistically, we found a decrease in arginase-1 produced by myeloid cells cultured in HN6 Sema4D-shRNA TCM, as well as a reduction in the immune suppressive cytokines, TGF- $\beta$, and IL-10.

\section{Conclusion}

This study describes a novel immunosuppressive mechanism for HNSCC through Sema4D induction of MDSCs. Collectively; our work highlights the therapeutic potential of Sema4D inhibition as a strategy to improve the efficacy of immunotherapy in HNSCC.

\section{Authors' details \\ 'School of Dentistry, University of Maryland Baltimore, Baltimore, MD, USA. ${ }^{2}$ School of Medicine, University of Maryland Baltimore, Baltimore, MD, USA.}

Published: 4 November 2015

\section{References}

1. Gildener-Leapman N, Ferris RL, Bauman JE: Promising systemic immunotherapies in head and neck squamous cell carcinoma. Oral Oncol 2013, 49(12):1089-1096.

2. Bismuth $G$, Boumsell $L$ : Controlling the immune system through semaphorins. SCi STKE 2002, 2002(128):re4.

3. Basile JR, Castilho RM, Williams VP, Gutkind JS: Semaphorin 4D provides a link between axon guidance processes and tumor-induced angiogenesis. Proc Natl Acad Sci 2006, 103(24):9017-9022. 
doi:10.1186/2051-1426-3-S2-P280

Cite this article as: Younis et al: Semaphorin 4D produced by human

head and neck squamous cell carcinoma induces myeloid derived

suppressor cells expansion from peripheral blood monocytes. Journal for ImmunoTherapy of Cancer 2015 3(Suppl 2):P280.

Submit your next manuscript to BioMed Central and take full advantage of:

- Convenient online submission

- Thorough peer review

- No space constraints or color figure charges

- Immediate publication on acceptance

- Inclusion in PubMed, CAS, Scopus and Google Scholar

- Research which is freely available for redistribution

Submit your manuscript at 